\author{
Federal Reserve Bank of Dallas \\ Globalization and Monetary Policy Institute \\ Working Paper No. 247 \\ http://www.dallasfed.org/assets/documents/institute/wpapers/2015/0247.pdf
}

\title{
The Cyclicality of (Bilateral) Capital Inflows and Outflows*
}

\author{
J. Scott Davis \\ Federal Reserve Bank of Dallas
}

August 2015

\begin{abstract}
Recent research has shown that gross capital inflows and outflows are positively correlated and highly procyclical. This poses a puzzle since most theory predicts that capital inflows and outflows should be negatively correlated, and while capital inflows should be procyclical, capital outflows should be countercyclical. This previous work has examined the behavior of aggregate capital inflows and outflows (capital flows between a country and the rest of the world). This paper shows that bilateral capital inflows and outflows (flows between a pair of countries) are also positively correlated and strongly procyclical. This empirical finding poses a new puzzle. The data suggests that any model that can explain capital flows at the bilateral level needs to rely on market incompleteness and non-diversification. In addition, the data suggests that this positive correlation and procyclicality is largely the feature of crisis episodes. After controlling for crisis episodes, we find that bilateral capital flows move positively with GDP in the country receiving the capital and co-move negatively in the country sending the capital.
\end{abstract}

JEL codes: F3, F4, G0, G1

\footnotetext{
* J. Scott Davis, Federal Reserve Bank of Dallas, Research Department, 2200 N. Pearl Street, Dallas, TX 75201. 214-922-5124. scott.davis@dal.frb.org. The views in this paper are those of the author and do not necessarily reflect the views of the Federal Reserve Bank of Dallas or the Federal Reserve System.
} 


\section{Introduction}

The European Central Bank established swap lines to provide euro liquidity to banks in Romania and Bulgaria in July 2015. A large fraction of the banking assets in Bulgaria and Romania are controlled by the affiliates of Greek parent banks. There was a fear that the brewing liquidity crisis in the Greek banking sector in the summer of 2015 could trigger a retrenchment by these Greek multi-national banks, leading to a sharp withdraw of liquidity from Romania and Bulgaria. Thus there was a fear that Greek banks may respond to a sudden stop in Greek capital inflows by decreasing their own capital outflows, leading to the spread of the crisis.(Financial Times, July 16, 2015)

Recent research has shown that gross capital inflows and outflows are highly correlated and both are procyclical.(Broner et al., 2013) This itself poses a puzzle that cannot be reconciled with a model where capital flows to its most productive use. After all, the workhorse international real business cycle model in Backus et al. (1994) is focused on explaining the positive correlation between GDP and net capital flows in the data. ${ }^{1}$ In the model capital flows into a country following a positive productivity shock. Thus in this framework, gross capital inflows are highly procycical and gross outflows and countercyclical, or in the words of Backus et al. (1995), "make hay while the sun shines".

Net capital inflows are equal to gross capital inflows minus gross capital outflows. The literature describing the effects of net capital flows discusses the effects of capital flow surges and sudden stops, as in Calvo et al. (1996) and Reinhart and Reinhart (2009). ${ }^{2}$ A surge is a sudden increase in net capital flows and a sudden stop is a sudden decrease. However, as shown by Forbes and Warnock (2012), when capital inflows and capital outflows are treated

\footnotetext{
${ }^{1}$ Net capital flows are simply the negative of the current account.

${ }^{2}$ Recent studies that have considered the causes of changes in net capital inflows include Ahmed and Zlate (2014) and Ghosh et al. (2014), among others. Papers that measure the effects of changes in net capital inflows include any paper that measures the macroeconomic effect of current account imbalances. See Rose and Spiegel (2011), Lane and Milesi-Ferretti (2011; 2012), and Frankel and Saravelos (2012) for some recent examples. These papers usually construct a series for net capital inflows by simply taking the negative of the current account, or taking the change in official reserves minus the current account if one wishes to concentrate on private capital flows.
} 
as two separate variables, the list of capital flow episodes expands. Forbes and Warnock (2012) define a surge to be a sudden increase in gross capital inflows and a stop to be a sudden decrease in inflows, but they also define a flight to be a sudden increase in capital outflows and a retrenchment to be a sudden decrease in capital outflows.

Rothenberg and Warnock (2011) argue that many observed sudden stops in net flows data are actually sudden flights. Forbes and Warnock (2012) show how due to this positive correlation between gross inflows and outflows, what we would normally identify as a surge in gross capital inflows may not appear as a surge in net capital inflows. This would happen if an increase in gross capital inflows is accompanied by an increase in gross capital outflows (in the words of Forbes and Warnock, a capital surge accompanied by a capital flight). At the other extreme, a sudden stop in gross capital inflows may not appear as a sudden stop in net capital inflows if the sudden stop in gross inflows is accompanied by a sharp retrenchment in gross capital outflows. They identify many episodes during the recent crisis where using data on net capital flows alone, we would actually claim that a country experienced a surge in capital flows. However, in nearly all of these countries, the surge in net capital inflows during the crisis was not due to a surge in capital inflows but rather was due to a sharp retrenchment in capital outflows. At the same time, using a definition based on net capital inflows, a handful of countries experienced a sudden stop during the crisis, but using a definition based on gross capital inflows, many more countries experienced a sudden stop.

Broner et al. (2013) also discuss the movements in gross capital inflows and outflows around the time of a crisis. They show that when there is a crisis in a given country gross capital inflows into that country decrease (a sudden stop), but gross capital outflows decrease as well (a retrenchment). When describing the sharp fall in gross inflows and outflows in the recent crisis, Milesi-Ferretti and Tille (2011) argue that a sharp increase in global risk led to retrenchment, and Giannetti and Laeven (2012) find strong evidence of retrenchment in what they call a "flight-to-home" (as opposed to a "flight-to-quality") as lenders cut their international exposure during the crisis. Tille and Van Wincoop (2008) construct a model where 
retrenchment can take place if foreign investors are less informed than domestic investors, and crises increase this information asymmetry. Tille and Van Wincoop (2010) construct a dynamic portfolio choice model where there is time-variation in second moments that affect home and foreign portfolios differently, and if this time variation in second moments is sufficient, the model will generate a positive correlation between gross inflows and outflows. ${ }^{3}$

From this it seems that an increase in global of country-specific risk around the time of a crisis and the tendency for that to drive retrenchment, or a "flight-to-home", seems to explain this observed positive correlation between gross inflows and outflows. However, using a data source that allows us to study the behavior of bilateral capital inflows and outflows (that is, capital inflows and outflows between a pair of countries) this paper will show that bilateral gross inflows and outflows are themselves highly correlated, and that this is true even after controlling for both a global risk factor and country-specific risk factors.

If capital inflows and outflows between a pair of countries are highly correlated because of a global risk shock that leads to global retrenchment, then after controlling for a global factor, bilateral inflows and outflows would not be positively correlated, and may be negatively correlated. If instead of a global factor, there is a factor specific to one of the two countries, like a banking crisis in one country, then this should lead to a decline of capital inflows into the crisis-struck country and if it leads to heightened risk aversion among residents of that country, it may lead to a retrenchment. In this way a country-specific factor may also lead to a positive correlation between bilateral inflows and outflows, but after controlling for aggregate capital flows in both countries, bilateral capital flows would be uncorrelated, or perhaps negatively correlated. The fact that the conditional correlation of bilateral inflows and outflows is positive, even after controlling for both a global factor and country-specific

\footnotetext{
${ }^{3}$ In a discussion of Broner et al. (2013), Bai (2013) mentions some other forces that might lead to a positive correlation between gross inflows and outflows, like multinational technology capital in McGrattan and Prescott (2010), reserve accumulation in Bianchi et al. (2012), or trade credits used to finance highly correlated import and exports. In addition Walsh (2014) constructs a model where sovereign default can lead to highly correlated and procycical gross inflows and outflows. But the given the data we use in this paper (bilateral banking transactions), we abstract from those channels here since they tend to focus on FDI flows, or government bond flows and reserves.
} 
aggregate inflows and outflows, poses a new puzzle.

Furthermore, with bilateral capital flows we can observe the cyclicality of capital inflows and outflows in both the country sending the capital and the country receiving the capital. Just as aggregate capital inflows and outflows are both highly procyclical, bilateral inflows and outflows are procyclical as well. Bilateral capital inflows and outflows positively co-move with GDP growth in both countries in the country pair. We then separate the co-movement with GDP during a crisis and the co-movement during normal times. The evidence strongly suggests that this procyclicality of both inflows and outflows is primarily centered around crisis periods. Once we control for the cyclicality of capital flows around the time of a crisis, capital inflows and outflows during normal periods follow the prescribed path from the international real business cycle literature. Capital inflows tend to be procyclical and capital outflows tend to be countercyclical; capital flows to its most productive use, 'making hay while the sun shines'.

This paper will proceed as follows. Section 2 will discuss some conceptual issues. The high conditional correlation between bilateral inflows and outflows, even after controlling for aggregate capital flows, poses a puzzle. This section will review some recent work on networks in international banking that can possibly explain this puzzle. The bilateral capital flows data is described in section 3. Section 4 discusses the correlation between bilateral capital inflows and outflows, and section 5 discusses the cyclicality of these bilateral inflows and outflows. Some sensitivity tests to test the robustness of these results are presented in section 6. Finally, section 7 concludes.

\section{Conceptual issues}

Dynamic portfolio choice models emphasize that changes in country-specific risk are responsible for the observed positive correlation between aggregate capital inflows and outflows. The study of bilateral capital flows allows us to see that there is something more than the 
general story of risk and retrenchment that is driving capital inflows and outflows. The fact that both bilateral inflows and outflows are positively correlated, even after controlling for both a global factor and country-specific aggregate capital inflows and outflows suggests that there must be something that drives this positive correlation apart from shocks that would drive aggregate capital inflows and outflows. The fact that the procyclicality of both capital inflows and outflows tends to be a feature of crises suggests that these forces that drive this high bilateral correlation must be especially pronounced during times of financial or banking crises.

The most likely culprit: a combination of liquidity effects and non-diversification. Acharya et al. (2011) discuss the effect of financial crises on banks' choice of liquidity. They find that a bank's liquidity choice is countercyclical; they choose to hold an inefficiently low amount of liquidity during economic booms but an excessively high amount during crises.Mendoza (2010) discusses how a sudden stop in capital inflows can tighten the credit constraint. Cetorelli and Goldberg (2011) and Cetorelli and Goldberg (2012) discuss liquidity management in large multi-national banks, and they show how these large multi-national banks move liquidity out of foreign affiliates back to the home parent bank in times of a crisis in the home country.

If a shock in a country causes aggregate capital inflows into that country to fall, then for liquidity reasons banks may be forced to retrench and decrease capital outflows. Thus liquidity management in response to a sudden stop in capital inflows can explain the high positive correlation between aggregate inflows and outflows around the time of a banking crisis.

Turning now to bilateral capital flows, suppose these is a sudden fall in bilateral capital inflows into country A from country B. Holding fixed aggregate capital inflows into country A from the rest of the world, if banks in country A are well diversified, the drop in capital inflows from country B will not lead to a liquidity squeeze in country A, and thus there is no reason that country A banks should retrench and reduce capital outflows to country B. 
But if a subset of banks in country A are over-exposed to country B both in assets and liabilities, then a fall in bilateral capital inflows would mean that this subset of banks would be forced to retrench and capital outflows from A to B would fall, even though total capital inflows and most other banks in country A are unaffected. Alternatively suppose all banks in country A are heavily exposed to country B, so capital inflows into country A from the rest of the world (not including B) is not as significant as bilateral capital inflows from country B. If bilateral capital inflows from B fall, banks in A may be faced with a liquidity squeeze would retrench leading to a fall in bilateral outflows, even when holding fixed capital inflows into country A from the rest of the world (not including B).

In a seminal paper on financial contagion, Allen and Gale (2000) discuss the role of nondiversification in financial contagion. Minoiu and Reyes (2013) and Hale (2012) characterize network relationships in global banking, and Minoiu et al. (2015) use the same data that is used in this paper to calculate how network-based measures of financial connectedness predict financial crises.

Buch et al. (2010) find that countries are over-exposed to some countries and underexposed to others in their cross-border banking, and they show that features like geography and culture are responsible for the over- or under-diversification. ${ }^{4}$ De Haas and Van Horen (2013) show that there is significant heterogeneity in how international lenders react to a crisis in a given country. And Anand et al. (2012) construct a game theoretic model of coordination failure that incorporates funding maturity and network structure to describe the interbank credit squeeze in 2008.

Thus the literature on networks in international banking shows that banks, both individual banks and national banking systems, tend to be non-diversified in their international claims and liabilities. The banking network literature has tended to focus on the role of these networks in financial contagion, but the results in this paper suggest that the effects

\footnotetext{
${ }^{4}$ Similarly, Portes and Rey (2005) examine the determinates of cross-border equity flows and find that many of the gravity variables that are used to describe trade flows (distance, language, culture, etc.) also affect equity flows.
} 
of banking networks and non-diversification may also explain large macro phenomenon like the positive co-movement between gross capital inflows and outflows.

Furthermore, in the theory this positive co-movement between gross inflows and gross outflows should be a feature of crisis periods, as both are strongly procyclical during a liquidity crisis as a sudden stop in capital inflows may trigger a liquidity squeeze and a retrenchment in capital outflows. If this is true then outside of crisis periods, capital flows will follow a more regular pattern with procyclical inflows and countercyclical outflows. That is exactly what we find in the data.

\section{Data}

Gross capital inflows are defined as the net purchases of domestic assets by foreign residents, and gross capital outflows are defined as net purchases of foreign assets by domestic residents.

Most papers that discuss capital flows are concerned with capital flows between a given country and the rest of the world. We will refer to these capital flows as aggregate gross capital inflows and outflows. We will refer to $C I_{i W t}$ as aggregate gross capital inflows into country $i$ from the rest of the world and $C O_{i W t}$ as aggregate gross capital outflows from country $i$ to the rest of the world. Net capital inflows are simply given by $C N_{i W t}=C I_{i W t}-$ $C O_{i W t}$.

For this data most papers rely on the IMF's Balance of Payments statistics International Monetary Fund (2009). While this data is comprehensive in that it includes debt, portfolio, and FDI flows, it only measures capital flows between a given country and the rest of the world. Using a more disaggregated dataset, this paper will discuss bilateral gross capital flows. Bilateral gross capital inflows into country $i$ from country $j$ are defined as the net purchase of country $i$ assets by country $j$ residents, $C I_{i j t}$, and bilateral gross capital outflows from country $i$ to country $j$ are defined as the net purchase of country $j$ assets by country $i$ residents, $\mathrm{CO}_{i j t} .^{5}$

\footnotetext{
${ }^{5}$ In this paper, if net purchases of foreign assets by domestic residents is positive, then there is capital
} 
The Bank for International Settlements (BIS) collects data on bilateral banking transactions. This Locational Banking Statistics data from the BIS has recently been used to study the channels of bilateral business cycle co-movement through integrated financial markets by Kalemli-Ozcan et al. (2013) and Kalemli-Ozcan et al. (2011). In addition, due to its bilateral nature, this data has been used to characterize cross-country banking networks (Minoiu and Reyes, 2013). In this dataset, BIS reporting banks within a country (the set of BIS reporting banks encompasses most banks, especially ones engaged in international transactions) report their stock of assets and liabilities with all parties, both banks and non-banks in another country. The BIS collects this data from banks in reporting countries on their assets and liabilities in vis-a-vis countries. The data is potentially available quarterly from 1978 to 2014, but to maximize the country coverage in this study, it is possible to get good data from 29 reporting countries starting in 1995 . There are many more vis-a-vis countries than reporting countries, but the analysis in this paper is restricted to pairs of reporting countries. This way the same capital flows are observed twice, when country $i$ is the reporting country and country $j$ is the vis-a-vis country, and when country $j$ is the reporting country and country $i$ is the vis-a-vis country.

This data is collected as stocks at current prices and exchange rates, so due to valuation effects simply taking the difference between observations in any two subsequent quarters does not give us an accurate picture of the actual financial flows from country $i$ to country $j$ over the quarter, but the BIS also produces a set of this data that has been corrected for these valuation effects and is appropriate for analyzing financial flows.

This is of course not an exhaustive set of capital flows. This BIS banking data cov-

flowing out of the country, and this is recorded as positive gross capital outflows. Similarly, if net purchases of domestic assets by foreign residents is positive, then there is capital flowing into the country and gross capital inflows are positive. In this way, net capital flows would be constructed by subtracting gross outflows from gross inflows, as in Broner et al. (2013). This is commonly referred to as the simple asset/liability approach from BPM6 accounting.

Some studies instead follow direction of flow principle from BPM5 accounting and consider that positive net purchases of foreign assets by domestic residents is a cash outflow from the domestic country and is recorded with a negative sign. In this case, net capital flows would be gross outflow plus gross inflows, as in Forbes and Warnock (2012). 
ers mainly bank lending, and excludes FDI flows and portfolio debt and equity flows. The primary reason for this choice is data availability. This BIS banking data is the most comprehensive time series of bilateral time series capital flow data available. ${ }^{6}$ In addition, FDI flows should be based more on long-term factors and less on cyclical factors. Available time series on portfolio flows (like the EPRF) both have a shorter time series and more importantly, are restricted to capital inflows from large financial centers. At the end of this section we will discuss some statistics that show that this BIS banking data provides a good proxy for actual capital flows, as measured in the Balance of Payments statistics.

The valuation corrected change in liabilities of country $i$ banks that are owed to counterparties in country $j$ is simply the purchase of assets in country $i$ by country $j$ residents, or bilateral gross capital inflows into country $i$ from country $j$. Similarly, the valuation corrected change in assets of country $i$ banks that are claims on country $j$ are simply bilateral gross capital outflows from country $i$ to country $j$. The statistics $C I_{i j t}$ and $C O_{i j t}$ are constructed by normalizing these gross capital inflows and outflows by the sum of the GDP in countries $i$ and $j$.

We can collect bilateral gross capital inflows and outflows for a total of 29 countries, so 406 country pairs. Given that capital flows between these countries constitute the vast majority of global capital flows, aggregate capital inflows and outflows in country $i$ would simply be defined as $C O_{i W t}=\sum_{k \in\{N \notin i\}} C O_{i k t}$ and $C I_{i W t}=\sum_{k \in\{N \notin i\}} C I_{i k t}$, where the set $N$ is the set of 29 countries in the study.

Later when calculating conditional correlation between capital inflows and outflows, it will be useful to define aggregate capital inflows and outflows in country $i$ from/to the rest of the world, not including country $j, C I_{i / j t}=\sum_{k \in\{N \notin i, j\}} C I_{i k t}=C I_{i W t}-C I_{i j t}$ and $C O_{i / j t}=\sum_{k \in\{N \notin i, j\}} C O_{i k t}=C O_{i W t}-C O_{i j t}$.

It is possible to compare our proxy series of aggregate capital inflows and outflows from the BIS data to the actual series of total aggregate capital inflows and outflows from the

\footnotetext{
${ }^{6}$ The CPIS data of portfolio debt and equity flows from the IMF is stocks and is not corrected for valuation effects.
} 
Balance of Payments data. Some sample statistics of aggregate capital inflows and outflows in the Balance of Payments data and in our proxy series constructed with the BIS banking data are presented in table 1 . The table shows that on average across the 29 countries in the study, the standard deviation of the capital inflows or outflows to GDP ratio in the Balance of Payments data is about 20\%. The standard deviation of the proxy measures for capital flows is a little less, although close. Furthermore, the correlation between the actual aggregate capital inflows and outflows and the proxy measures is about 0.66 , indicating that these proxy measures can track the actual measures of capital flows very well.

In addition, some of the regression models in this paper use a 0-1 banking crisis indicator variable to distinguish between the cyclicality of capital flows in tranquil times and during crisis times. This indicator variable is taken from Reinhart and Reinhart (2009) and Reinhart and Rogoff (2009). We also confirm that these results are robust to an alternative banking crisis indicator variable developed in Laeven and Valencia (2013). The banking crisis indicator variables are available at an annual frequency and the capital flow data in this study is quarterly. We convert this annual crisis indicator variable into a quarterly variable by simply assuming that if the variable is equal to 1 in a given year, it is equal to on in each quarter of that year.

\section{Correlation of Gross Inflows and Outflows}

The first step to understanding the cyclicality of these gross capital flows is to observe that these gross capital inflows and outflows are themselves highly correlated.

Why they are correlated is another question. Capital inflows and outflows could have a high unconditional correlation, but if that is simply due to a global factor like a global risk shock, then after we control for a global factor, the conditional correlation will not be positive. To test if a global factor alone is responsible for the positive correlation between aggregate capital inflows and outflows, first regress aggregate inflows and outflows, $C I_{i W t}$ and 
$C O_{i W t}$, on a time fixed effect in a panel data regression across quarters and all 29 countries in the sample. The conditional correlation is simply the correlation between the residuals from these two regressions.

Conditional correlation in this panel data study can be calculated two ways, as correlation across countries in a given quarter, or correlation across time for a given country. Some simple statistics describing these cross-sectional or cross-time correlations are listed in the first and third columns of table 2 . The table shows that the conditional correlation of aggregate capital inflows and outflows, after controlling for a global factor, are still very positive. This tells us that a global factor alone is not responsible for the co-movement of aggregate capital inflows and outflows.

The next possibility is a country-specific risk shock. This could be a crisis in a given country. Capital inflows into that country would of course fall, and if the heightened risk and risk aversion causes domestic residents to retrench, we would observe a positive correlation between aggregate capital inflows and outflows, and since the shock is country-specific and not a global factor, the conditional correlation would also be positive after controlling for a global factor.

Using only data on aggregate capital inflows and outflows we can't go any further in calculating conditional correlations. However, using data for bilateral capital flows, we can calculate the conditional correlation between $C I_{i j t}$ and $C O_{i j t}$, controlling for both a global factor and country-specific aggregate capital inflows and outflows. If the country-shock is driving this positive correlation, then after controlling for aggregate inflows and outflows in both countries in the country pair, the conditional correlation between bilateral inflows and outflows will not be positive. To calculate this conditional correlation we regress $C I_{i j t}$ and $C O_{i j t}$ on a time fixed effect, and aggregate inflows and outflows in countries $i$ and $j$ from/to the rest of the world, not including countries $i$ and $j: C I_{i / j t}, C I_{j / i t}, C O_{i / j t}$, and $C O_{j / i t}$.

The correlation between bilateral capital inflows and outflows, after controlling for both a global factor and country-specific factors, is shown in the second and fourth columns of 
table 2. The conditional correlation of these bilateral capital flows is still positive and around 0.4, although it is less than the conditional correlation between aggregate capital flows. This suggests that these country shocks do explain some of the positive correlation between capital inflows and outflows, but not all of the positive correlation.

Another way to measure the strong co-movement between gross inflows and outflows is simply to regress gross inflows on gross outflows, and vice versa. We first run these two simple regressions using aggregate gross capital inflows and outflows:

$$
\begin{aligned}
C I_{i W t} & =\beta C O_{i W t}+\varepsilon_{i t} \\
C O_{i W t} & =\gamma C I_{i W t}+\epsilon_{i t}
\end{aligned}
$$

and thus $\beta$ measures the co-movement between aggregate gross capital inflows and aggregate gross outflows, and $\gamma$ measures the response of outflows to a change in inflows. Both country and period fixed effects are included in each regression. The results from these regressions are presented in the top half of table 3 . The results in the table show that aggregate gross capital inflows and aggregate gross capital outflows are highly correlated.

The regression in (1) is certainly informative about the co-movement between aggregate gross inflows and aggregate gross outflows, but of course it doesn't allow us to identify the drivers of these capital flows.

The data for bilateral gross inflows and outflows allow us to test how these gross capital flows are affected by conditions in both the country sending the capital and the country receiving the capital. To test how bilateral capital flows between a pair of countries is affected by aggregate capital flows in both the sending and the receiving country, we can run the following regressions: 


$$
\begin{aligned}
C I_{i j t} & =\beta_{1} C I_{i W t}+\beta_{2} C O_{j W t}+\varepsilon_{i j t} \\
C O_{i j t} & =\gamma_{1} C O_{i W t}+\gamma_{2} C I_{j W t}+\epsilon_{i j t}
\end{aligned}
$$

where country-pair and period fixed effects are included in each regression. In this regression, $\beta_{1}$ measures the co-movement between bilateral gross inflows into country $i$ from country $j$ and aggregate gross capital inflows into country $i$, and $\beta_{2}$ measures the co-movement between bilateral gross inflows into country $i$ from country $j$ and aggregate capital outflows from country $j$. Thus if there is an increase in aggregate capital inflows into country $i$, that should lead to an increase in bilateral inflows into country $i$ from country $j$ of $\beta_{1}$. Similarly, if there is an increase in aggregate capital outflows from country $j$, capital inflows into country $i$ from country $j$ will increase by $\beta_{2}$. The second regression in (2) asks a similar question, except now the dependent variable is bilateral gross outflows from country $i$ to country $j$, so now we wish to measure how these bilateral flows depend on aggregate gross outflows from country $i$ and aggregate gross inflows into country $j$.

Alternatively we could run the following regressions:

$$
\begin{aligned}
C I_{i j t} & =\beta_{1} C I_{i W t}+\beta_{2} C O_{j W t}+\beta_{3} C O_{i j t}+\varepsilon_{i j t} \\
C O_{i j t} & =\gamma_{1} C O_{i W t}+\gamma_{2} C I_{j W t}+\gamma_{3} C I_{i j t}+\epsilon_{i j t}
\end{aligned}
$$

In these regressions, if the estimates of $\beta_{3}$ or $\gamma_{3}$ are significantly greater than zero then that suggests that bilateral gross capital inflows and outflows between two countries are highly correlated, even after controlling for aggregate capital flows. The results from these regressions are included in the first and third column of the tables in the bottom half of table 3. The results show that when bilateral capital flows between $i$ and $j$ are regressed on aggregate capital outflows and inflows to and from countries $i$ and $j$, these aggregate capital 
flows are significant predictors of bilateral capital flows. Both aggregate capital inflows into country $i$ and aggregate capital outflows from country $j$ have a positive and significant effect on bilateral capital inflows from country $j$ into country $i$, and the same is true when bilateral outflows from country $i$ to country $j$ is the dependent variable, but the adjusted $R^{2}$ shows that cross country variation in aggregate capital inflows or outflows actually explains very little of the cross-country pair variation in bilateral capital flows. Bilateral inflows or outflows are included in the regression in the second and fourth columns of the table. The table shows that the sign of these bilateral gross capital flows are positive and significant, indicating that bilateral gross inflows and outflows are highly correlated, even after controlling for aggregate capital inflows and outflows. The coefficients of aggregate capital flows are smaller, indicating that when we control for bilateral capital outflows from $i$ to $j$, aggregate capital flows in country $i$ or country $j$ are not near as important for explaining bilateral capital inflows into $i$ from $j$. Furthermore, the adjusted $R^{2}$ in the regressions in the second and fourth column is significantly higher, indicating that cross-country pair variation in bilateral capital inflows into country $i$ from country $j$ explains $31 \%$ of cross-country pair variation in bilateral capital outflows from country $i$ to country $j$, and vice versa.

\section{Cyclicality of Capital Inflows and Outflows}

After establishing that bilateral capital inflows and outflows are highly correlated, let us turn now to the cyclicality of these gross capital flows. Using the panel of aggregate gross capital inflows and outflow, we can estimate the following:

$$
Z_{i W t}=\sum_{\tau=1}^{4} \beta_{1 \tau} \Delta y_{i t-\tau}+\sum_{\tau=1}^{4} \beta_{2 \tau} \Delta y_{i t-\tau} \times \text { Crisis }_{i t-\tau}+\varepsilon_{i t}
$$

where $Z_{i W t}=C I_{i W t}, C O_{i W t}$, or $C N_{i W t}$ and $\Delta y_{i t-\tau}$ is the log change in real GDP in country $i$ from period $t-\tau-1$ to period $t-\tau$. We begin by setting $\beta_{2 \tau}=0$. In this case if $\sum_{\tau=1}^{4} \beta_{1 \tau}$ is positive and significant then aggregate gross capital inflows or outflows are procyclical. If 
we remove the restriction that $\beta_{2 \tau}=0$ then we allow the possibility that the cyclicality of capital flows may be different in crisis times than in non-crisis times. In this case $\sum_{\tau=1}^{4} \beta_{1 \tau}$ measure the effect of GDP growth on capital inflows and outflows during normal periods, and $\sum_{\tau=1}^{4} \beta_{1 \tau}+\sum_{\tau=1}^{4} \beta_{2 \tau}$ measure the effect on capital inflows and outflows during a banking crisis in country $i$.

The results from the regression using aggregate gross inflows and outflows are presented in the top half of table 4 . The first and third columns of the table show that both aggregate inflows and outflows are procyclical, although the point estimate is greater for capital inflows, indicating that net capital inflows are procyclical, as shown in the fifth column. The number reported in the table is the sum of the coefficients from the four lags of GDP growth, so the numbers presented in the first column of the table are the point estimate and standard error of $\sum_{\tau=1}^{4} \beta_{1 \tau}$. The point estimate indicates that a one percentage point increase in GDP growth over the past year leads to a 3.3 percentage point increase in aggregate gross capital inflows and a 2.2 percentage point increase in aggregate outflows. The results from including an interaction term between GDP growth and the banking crisis indicator variable are reported in the second and fourth columns. The numbers in the third and fourth row of the second column of the table are the point estimate and standard error of $\sum_{\tau=1}^{4} \beta_{2 \tau}$. Both country and period fixed effects are included in each regression.

The table shows that during normal times, the coefficients of GDP growth are insignificant, indicating that both aggregate gross capital inflows and outflows are acyclical during normal times. However, the results show that during a crisis, aggregate capital inflows and outflows are both highly procyclical. During a crisis, a one percentage point fall in GDP growth over the past year leads to a 3 percentage point decrease in aggregate gross capital inflows and a 2 percentage point decrease in aggregate capital outflows. ${ }^{7}$ So during a crisis,

\footnotetext{
${ }^{7}$ The effect of GDP growth on capital inflows during a crisis is $\sum_{\tau=1}^{4} \beta_{1 \tau}+\sum_{\tau=1}^{4} \beta_{2 \tau} \approx 3$ and the effect on capital outflows is $\sum_{\tau=1}^{4} \gamma_{1 \tau}+\sum_{\tau=1}^{4} \gamma_{2 \tau} \approx 2$.
} 
there is both a stop in aggregate capital inflows and a retrenchment in aggregate capital outflows.

These regressions using aggregate capital flows allow us to measure the cyclicality of capital inflows and outflows in country $i$, but using bilateral gross inflows and outflows, we can measure how capital inflows and outflows react to macroeconomic conditions in both the sending and receiving countries. To do this we estimate the following regressions:

$$
\begin{aligned}
Z_{i j t}= & \sum_{\tau=1}^{4} \beta_{1 \tau}^{i} \Delta y_{i t-\tau}+\sum_{\tau=1}^{4} \beta_{1 \tau}^{j} \Delta y_{j t-\tau} \\
& +\sum_{\tau=1}^{4} \beta_{2 \tau}^{i} \Delta y_{i t-\tau} \times \text { Crisis }_{i t-\tau}+\sum_{\tau=1}^{4} \beta_{2 \tau}^{j} \Delta y_{j t-\tau} \times \text { Crisis }_{j t-\tau}+\varepsilon_{i j t}
\end{aligned}
$$

for $Z_{i j t}=C I_{i j t}, C O_{i j t}$, or $C N_{i j t}$. The results from these regressions of bilateral gross capital inflows and outflows are presented in the bottom half of table 4 . The first, third and fifth columns present the results from the regression where $\beta_{2 \tau}^{i}=\beta_{2 \tau}^{j}=0$. Bilateral capital inflows and bilateral capital outflows both depend positively on GDP growth in both the sending and receiving countries. Thus even at the bilateral level, capital inflows and outflows are strongly procyclical. Although the point estimates show that capital inflows respond more to GDP growth in the first country in the pair than the second (the country receiving the capital), and the capital outflows respond more strongly to GDP growth in the second country in the country pair (the country receiving the capital). And thus net capital inflows from country $j$ to country $i$ co-move positively with GDP in country $i$ and negatively with GDP in country $j$.

The results in the second, fourth, and sixth columns remove the restriction $\beta_{2 \tau}^{i}=\beta_{2 \tau}^{j}=0$ and allow the cyclicality of bilateral capital flows to be different in normal times than in crisis times. The results show that the observed procyclicality of both bilateral capital inflows and outflows is because these capital flows are procyclical during banking crisis periods. The results in the second column show that bilateral inflows to country $i$ from country $j$ co-move 
negatively with GDP in country $j$ while bilateral outflows co-move positively with GDP in country $j$. Thus in non-crisis times, capital inflows tend to be procycical and capital outflows tend to be counter cyclical, exactly as conventional theory would predict.

\section{Sensitivity tests}

This BIS locational banking statistics records capital flows from banks in a reporting country to all counterparties, both banks and non-banks in a vis-a-vis country. Therefore the accumulation of assets in country $i$ on counterparties in country $j$ is a capital outflow from reporting country $i$ to vis-a-vis country $j, C O_{i j t}$. By limiting the country coverage to pairs of reporting countries, we also observe data when country $j$ is a reporting country and country $i$ is vis-a-vis. The accumulation of liabilities by banks in country $j$ from counterparties in country $i$ is simply the gross capital inflows into $j$ from $i, C I_{j i t}$. If all counterparties in the vis-a-vis country were banks, then in theory $C O_{i j t}=C I_{j i t}$. A bank-to-bank capital outflow from $i$ to $j$ we observe twice, as an asset when $i$ is the reporting country and as a liability when $j$ is the reporting country, but a capital outflow from a bank in country $i$ to a non-bank in country $j$ we only observe when $i$ is a reporting country.

This fact allows a convenient sensitivity test when using data for aggregate capital flows. Recall that aggregate capital inflows and outflows are constructed by summing all bilateral capital inflows and outflows with the other countries in the sample:

$$
\begin{aligned}
C O_{i W t} & =\sum_{k \in\{N \notin i\}} C O_{i k t} \\
C I_{i W t} & =\sum_{k \in \tilde{N}} C I_{i k t}
\end{aligned}
$$

Here when constructing the measure of aggregate capital flows for country $i$, we are considering the data where country $i$ is the reporting country. On the other hand we can construct 
the measure of aggregate capital flows where country $i$ is the vis-a-vis country:

$$
\begin{aligned}
C O_{i W t} & \approx C I_{W i t}=\sum_{k \in\{N \notin i\}} C I_{k i t} \\
C I_{i W t} & \approx C O_{W i t}=\sum_{k \in\{N \notin i\}} C O_{k i t}
\end{aligned}
$$

The main results from the paper, both the regressions measuring the co-movement of aggregate inflows and outflows and the regressions measuring the cyclicality of aggregate capital flows are presented in the top halves of tables 5 and 6 . The tables show that the results are qualitatively and nearly quantitatively the same as in the main results in the last section. Aggregate capital inflows and outflows co-move positively, and capital outflows are acyclical during normal times but strongly procyclical during crisis times.

Similarly, the way the data is constructed builds in a useful robustness check in the bilateral data. In the main analysis presented in the last section, we considered both country pairs $i j$ and the opposite $j i$. This potentially double counts any capital flows between BIS reporting banks, but it is sure to capture all capital flows where a non-bank is a counterparty. Alternatively we could restrict the analysis and allow each country pair to be counted only once. This would eliminate any double counting of bank-to-bank flows but would exclude some bank-to-non-bank flows. In this sensitivity analysis we will restrict attention to country pairs $i j$ where the GDP per capita in country $i$ is greater than that in country $j .{ }^{8}$

The main results from the paper, both the regressions measuring the co-movement of aggregate inflows and outflows and the regressions measuring the cyclicality of aggregate capital flows are presented in the bottom halves of tables 5 and 6 . Here we again see that bilateral capital flows co-move positively after controlling for aggregate capital flows.

\footnotetext{
${ }^{8}$ Sorting country pairs by GDP per capita is simply an arbitrary way to sort the data and ensure that we do not include pairs $i j$ and $j i$ in the same regression.
} 


\section{Summary and Conclusion}

The fact that capital inflows and outflows are positively correlated poses a puzzle to our existing suite of international real business cycle models. This fact can be reconciled in a dynamic portfolio choice model by introducing country-specific risk shocks, but the results in this paper, with the high correlation between bilateral inflows and outflows, even after controlling for changes in aggregate capital flows further complicates this puzzle.

The results in this paper show that a lot of this positive correlation between bilateral capital inflows and outflows, and thus between aggregate capital inflows and outflows, may be driven by network effects and non-diversification in international banking relationships. If this positive co-movement between capital inflows and outflows is largely a product of banking network relationships and liquidity crises, then outside of these liquidity crisis periods, a more normal and relationship between capital inflows and outflows should emerge. Using data on bilateral capital flows we can do exactly that, and while bilateral inflows and outflows tend to be procyclical in both countries in the bilateral pair, after controlling for crisis periods, during normal times capital inflows tend to co-move positively with the

country receiving the capital and negatively with the country sending the capital, exactly as theory would predict. 


\section{References}

Acharya, V. V., Shin, H. S., Yorulmazer, T., 2011. Crisis resolution and bank liquidity. Review of Financial studies 24 (6), 2166-2205.

Ahmed, S., Zlate, A., 2014. Capital flows to emerging market economies: a brave new world? Journal of International Money and Finance 48, 221-248.

Allen, F., Gale, D., 2000. Financial contagion. Journal of Political Economy 108, 1-33.

Anand, K., Gai, P., Marsili, M., 2012. Rollover risk, network structure and systemic financial crises. Journal of Economic Dynamics and Control 36 (8), 1088-1100.

Backus, D. K., Kehoe, P. J., Kydland, F. E., 1994. Dynamics of the trade balance and the terms of trade: The j-curve? American Economic Review 84, 84-103.

Backus, D. K., Kehoe, P. J., Kydland, F. E., 1995. International business cycles: Theory and evidence. In: Cooley, T. (Ed.), Frontiers of Business Cycle Research. Princeton University Press, pp. 331-356.

Bai, Y., 2013. Discussion on Şgross capital flows: Dynamics and crises ̌̌ by broner, didier, erce, and schmukler. Journal of Monetary Economics 60 (1), 134-137.

Bianchi, J., Hatchondo, J. C., Martinez, L., December 2012. International reserves and rollover risk. NBER Working Paper No. 18628.

Broner, F., Didier, T., Erce, A., Schmukler, S. L., 2013. Gross capital flows: Dynamics and crises. Journal of Monetary Economics 60 (1), 113-133.

Buch, C. M., Driscoll, J. C., Ostergaard, C., 2010. Cross-border diversification in bank asset portfolios*. International Finance 13 (1), 79-108.

Calvo, G. A., Leiderman, L., Reinhart, C. M., 1996. Inflows of capital to developing countries in the 1990s. The Journal of Economic Perspectives 10 (2), 123-139.

Cetorelli, N., Goldberg, L. S., 2011. Global banks and international shock transmission: Evidence from the crisis. IMF Economic Review 59, 41-76.

Cetorelli, N., Goldberg, L. S., 2012. Liquidity management of us global banks: Internal capital markets in the great recession. Journal of International Economics 88 (2), 299311.

De Haas, R., Van Horen, N., 2013. Running for the exit? international bank lending during a financial crisis. Review of Financial Studies 26 (1), 244-285.

Financial Times, July 16, 2015. ECB puts in place secret credit lines with Bulgaria and Romania. Financial Times.

Forbes, K., Warnock, F. E., 2012. Capital flow waves: Surges, stops, flight, and retrenchment. Journal of International Economics 88, 235-251. 
Frankel, J. A., Saravelos, G., 2012. Can leading indicators assess country vulnerability? evidence from the 2008 Ü09 global financial crisis. Journal of International Economics 87 (2), 216-231.

Ghosh, A. R., Qureshi, M. S., Kima, J. I., Zalduendo, J., 2014. Surges. Journal of International Economics 92, 266-285.

Giannetti, M., Laeven, L., 2012. The flight home effect: Evidence from the syndicated loan market during financial crises. Journal of Financial Economics 104 (1), 23-43.

Hale, G., 2012. Bank relationships, business cycles, and financial crises. Journal of International Economics 88 (2), 312-325.

International Monetary Fund, 2009. Balance of Payments and International Investment Position Manual. International Monetary Fund, Washington D.C.

Kalemli-Ozcan, S., Papaioannou, E., Perri, F., 2011. Global banks and crisis transmission. mimeo.

Kalemli-Ozcan, S., Papaioannou, E., Peydro, J. L., 2013. Financial regulation, financial globalization, and the synchronization of economic activity. Journal of Finance 68 (3), 1179-1228.

Laeven, L., Valencia, F., 2013. Systematic banking crises database. IMF Economic Review 61, 225-270.

Lane, P. R., Milesi-Ferretti, G. M., 2011. The cross-country incidence of the global crisis. IMF Economic Review 59, 77-110.

Lane, P. R., Milesi-Ferretti, G. M., 2012. External adjustment and the global crisis. Journal of International Economics 88 (2), 252-265.

McGrattan, E. R., Prescott, E. C., 2010. Technology capital and the us current account. The American economic review 100 (4), 1493-1522.

Mendoza, E. G., 2010. Sudden stops, financial crises, and leverage. The American Economic Review 100 (5), 1941-1966.

Milesi-Ferretti, G. M., Tille, C., 2011. The great retrenchment: International capital flows during the global financial crisis. Economic Policy 26 (66), 285-342.

Minoiu, C., Kang, C., Subrahmanian, V., Berea, A., 2015. Does financial connectedness predict crises? Quantitative Finance 15 (4), 607-624.

Minoiu, C., Reyes, J. A., 2013. A network analysis of global banking: 1978-2010. Journal of Financial Stability 9 (2), 168-184.

Portes, R., Rey, H., 2005. The determinants of cross-border equity flows. Journal of International Economics 65, 269-296. 
Reinhart, C., Reinhart, V., 2009. Capital flow bonanzas: An encompassing view of the past and present. NBER International Seminar on Macroeconomics 2008, 9-62.

Reinhart, C. M., Rogoff, K. S., 2009. This Time is Different: Eight Centuries of Financial Folly. Princeton University Press, Priceton, N.J.

Rose, A. K., Spiegel, M. M., 2011. Cross-country causes and consequences of the crisis: An update. European Economic Review 55 (3), 309-324.

Rothenberg, A. D., Warnock, F. E., 2011. Sudden flight and true sudden stops. Review of International Economics 19 (3), 509-524.

Tille, C., Van Wincoop, E., 2008. International capital flows under dispersed information: Theory and evidence. NBER Working Paper No. 14390.

Tille, C., Van Wincoop, E., 2010. International capital flows. Journal of international Economics 80 (2), 157-175.

Walsh, K., 2014. Portfolio choice and partial default in emerging markets: a quantitative analysis. mimeo. 
Table 1: Statistics comparing actual capital inflows from the Balance of Payments statistics to the proxy constructed from the BIS bankng data.

\begin{tabular}{|c|c|c|c|c|c|}
\hline St. Dev. & $\begin{array}{r}\text { Mean } \\
\text { Median }\end{array}$ & $\begin{array}{r}C I_{B O P} \\
21.14 \\
12.89\end{array}$ & $\begin{array}{r}C I_{B I S} \\
14.40 \\
9.22\end{array}$ & $\begin{array}{r}C O_{B O P} \\
20.85 \\
12.47\end{array}$ & $\begin{array}{r}C O_{B I S} \\
13.75 \\
8.75\end{array}$ \\
\hline Correlation & $\begin{array}{r}\text { Mean } \\
\text { Median }\end{array}$ & & $\begin{array}{l}0.66 \\
0.65\end{array}$ & & $\begin{array}{l}0.64 \\
0.68\end{array}$ \\
\hline
\end{tabular}

Table 2: The correlation of aggregate or bilateral gross capital inflows and outflows.

\begin{tabular}{|c|c|c|c|c|}
\hline & \multicolumn{2}{|c|}{ Across Countries in a Given Quarter } & \multicolumn{2}{|c|}{ Across Quarters in a Given Country } \\
\hline & Aggregate & Bilateral & Aggregate & Bilateral \\
\hline Mean & 0.734 & 0.399 & 0.758 & 0.437 \\
\hline Median & 0.792 & 0.397 & 0.832 & 0.445 \\
\hline 25th Percentile & 0.661 & 0.238 & 0.661 & 0.234 \\
\hline 75th Percentile & 0.875 & 0.536 & 0.896 & 0.648 \\
\hline
\end{tabular}


Table 3: Results from the regression of aggregate or bilateral capital inflows and outflows on aggregate and bilateral outflows and inflows.

\begin{tabular}{|c|c|c|c|c|c|}
\hline Dependent variable: & $C I_{i W t}$ & $C O_{i W t}$ & & & \\
\hline$C O_{i W t}$ & $\begin{array}{r}0.969^{* * *} \\
(0.012)\end{array}$ & & & & \\
\hline$C I_{i W t}$ & & $\begin{array}{r}0.799^{* * *} \\
(0.010)\end{array}$ & & & \\
\hline Period FE & Yes & Yes & & & \\
\hline Cross-section FE & Yes & Yes & & & \\
\hline $\bar{R}^{2}$ & 0.781 & 0.783 & & & \\
\hline Obs. & 1984 & 1984 & & & \\
\hline Dependent variable: & $C I_{i j t}$ & $C I_{i j t}$ & & $C O_{i j t}$ & $C O_{i j t}$ \\
\hline$C I_{i W t}$ & $\begin{array}{r}0.004^{* * *} \\
(0.000)\end{array}$ & $\begin{array}{r}0.002^{* * *} \\
(0.000)\end{array}$ & $C O_{i W t}$ & $\begin{array}{r}0.004^{* * *} \\
(0.000)\end{array}$ & $\begin{array}{r}0.002^{* * *} \\
(0.000)\end{array}$ \\
\hline$C O_{j W t}$ & $\begin{array}{r}0.006^{* * *} \\
(0.000)\end{array}$ & $\begin{array}{r}0.004^{* * *} \\
(0.000)\end{array}$ & & $\begin{array}{r}0.005^{* * *} \\
(0.000)\end{array}$ & $\begin{array}{r}0.004^{* * *} \\
(0.000)\end{array}$ \\
\hline$C O_{i j t}$ & & $\begin{array}{r}0.460^{* * * *} \\
(0.004)\end{array}$ & $C I_{i j t}$ & & $\begin{array}{r}0.573^{* * *} \\
(0.005)\end{array}$ \\
\hline Period FE & Yes & Yes & & Yes & Yes \\
\hline Cross-section FE & Yes & Yes & & Yes & Yes \\
\hline $\bar{R}^{2}$ & 0.058 & 0.314 & & 0.059 & 0.314 \\
\hline Obs. & 38954 & 38032 & & 38676 & 38032 \\
\hline
\end{tabular}


Table 4: Results from the regression of capital inflows and outflows on lags of GDP growth.

\begin{tabular}{|c|c|c|c|c|c|c|}
\hline Dependent variable: & $C I_{i W t}$ & $C I_{i W t}$ & $C O_{i W t}$ & $C O_{i W t}$ & $C N_{i W t}$ & $C N_{i W t}$ \\
\hline$\Delta y_{i t}$ & $\begin{array}{r}3.330^{* * *} \\
(1.109)\end{array}$ & $\begin{array}{r}0.479 \\
(0.766)\end{array}$ & $\begin{array}{r}2.225^{* *} \\
(1.008)\end{array}$ & $\begin{array}{r}0.113 \\
(0.668)\end{array}$ & $\begin{array}{r}1.104^{* *} \\
(0.529)\end{array}$ & $\begin{array}{r}0.366 \\
(0.528)\end{array}$ \\
\hline$\Delta y_{i t} \times C r i s i s_{i t}$ & & $\begin{array}{r}2.477^{* *} \\
(1.129)\end{array}$ & & $\begin{array}{r}2.031^{* *} \\
(0.985)\end{array}$ & & $\begin{array}{r}0.446 \\
(0.778)\end{array}$ \\
\hline Period FE & Yes & Yes & Yes & Yes & Yes & Yes \\
\hline Cross-section FE & Yes & Yes & Yes & Yes & Yes & Yes \\
\hline $\bar{R}^{2}$ & 0.037 & 0.137 & 0.046 & 0.185 & 0.050 & 0.045 \\
\hline Obs. & 1855 & 1675 & 1855 & 1675 & 1855 & 1675 \\
\hline Dependent variable: & $C I_{i j t}$ & $C I_{i j t}$ & $C O_{i j t}$ & $C O_{i j t}$ & $C N_{i j t}$ & $C N_{i j t}$ \\
\hline$\Delta y_{i t}$ & $\begin{array}{r}0.039^{* * *} \\
(0.008)\end{array}$ & $\begin{array}{r}-0.001 \\
(0.009)\end{array}$ & $\begin{array}{r}0.022^{* *} \\
(0.009)\end{array}$ & $\begin{array}{r}-0.012 \\
(0.010)\end{array}$ & $\begin{array}{r}0.018^{* *} \\
(0.008)\end{array}$ & $\begin{array}{r}0.010 \\
(0.010)\end{array}$ \\
\hline$\Delta y_{j t}$ & $\begin{array}{c}0.011^{*} \\
(0.006)\end{array}$ & $\begin{array}{r}-0.015^{* *} \\
(0.007)\end{array}$ & $\begin{array}{r}0.041^{* * * *} \\
(0.007)\end{array}$ & $\begin{array}{c}0.013^{*} \\
(0.008)\end{array}$ & $\begin{array}{r}-0.031^{* * *} \\
(0.007)\end{array}$ & $\begin{array}{r}-0.030^{* * *} \\
(0.008)\end{array}$ \\
\hline$\Delta y_{i t} \times$ Crisis $_{i t}$ & & $\begin{array}{r}0.094^{* * * *} \\
(0.016)\end{array}$ & & $\begin{array}{r}0.053^{* * *} \\
(0.018)\end{array}$ & & $\begin{array}{r}0.042^{* *} \\
(0.018)\end{array}$ \\
\hline$\Delta y_{j t} \times$ Crisis $_{j t}$ & & $\begin{array}{r}0.038^{* * * *} \\
(0.010)\end{array}$ & & $\begin{array}{r}0.032^{* * * *} \\
(0.011)\end{array}$ & & $\begin{array}{r}0.006 \\
(0.011)\end{array}$ \\
\hline Period FE & Yes & Yes & Yes & Yes & Yes & Yes \\
\hline Cross-section FE & Yes & Yes & Yes & Yes & Yes & Yes \\
\hline $\bar{R}^{2}$ & 0.012 & 0.022 & 0.013 & 0.021 & 0.019 & 0.019 \\
\hline Obs. & 38889 & 32744 & 38609 & 32536 & 37967 & 32092 \\
\hline
\end{tabular}

Notes: The coefficient in the table is the sum of the coefficients from the four lags of GDP growth. Cross-sectional fixed effects are country fixed

effects in the case of regressions of aggregate gross capital flows and country-pair fixed effects in the case of regressions of bilateral gross capital flows. Standard errors in parenthesis. *** denotes significance at the $1 \%$ level, ** at the $5 \%$ level, and * at the $10 \%$ level. 
Table 5: Sensitivity results from the regression of aggregate or bilateral capital inflows and outflows on aggregate and bilateral outflows and inflows.

\begin{tabular}{|c|c|c|c|c|c|}
\hline \multirow{2}{*}{$\begin{array}{l}\text { Dependent variable: } \\
\qquad C O_{i W t}\end{array}$} & $C I_{i W t}$ & $C O_{i W t}$ & & \multirow[b]{8}{*}{$C O_{i j t}$} & \multirow[b]{8}{*}{$C O_{i j t}$} \\
\hline & $\begin{array}{r}0.624^{* * *} \\
(0.025)\end{array}$ & & & & \\
\hline$C I_{i W t}$ & & $\begin{array}{r}0.389^{* * *} \\
(0.016)\end{array}$ & & & \\
\hline Period FE & Yes & Yes & & & \\
\hline Cross-section FE & Yes & Yes & & & \\
\hline $\bar{R}^{2}$ & 0.308 & 0.303 & & & \\
\hline Obs. & 1979 & 1979 & & & \\
\hline Dependent variable: & $C I_{i j t}$ & $C I_{i j t}$ & & & \\
\hline$C I_{i W t}$ & $\begin{array}{r}0.003^{* * *} \\
(0.000)\end{array}$ & $\begin{array}{r}0.002^{* * *} \\
(0.000)\end{array}$ & $C O_{i W t}$ & $\begin{array}{r}0.003^{* * *} \\
(0.000)\end{array}$ & $\begin{array}{r}0.002^{* * *} \\
(0.000)\end{array}$ \\
\hline$C O_{j W t}$ & $\begin{array}{r}0.005^{* * *} \\
(0.000)\end{array}$ & $\begin{array}{r}0.004^{* * * *} \\
(0.000)\end{array}$ & & $\begin{array}{r}0.005^{* * * *} \\
(0.000)\end{array}$ & $\begin{array}{r}0.004^{* * *} \\
(0.000)\end{array}$ \\
\hline$C O_{i j t}$ & & $\begin{array}{r}0.407^{* * *} \\
(0.006)\end{array}$ & $C I_{i j t}$ & & $\begin{array}{r}0.416^{* * *} \\
(0.006)\end{array}$ \\
\hline Period FE & Yes & Yes & & Yes & Yes \\
\hline Cross-section FE & Yes & Yes & & Yes & Yes \\
\hline $\bar{R}^{2}$ & 0.068 & 0.231 & & 0.072 & 0.236 \\
\hline Obs. & 23293 & 22846 & & 23225 & 22846 \\
\hline
\end{tabular}


Table 6: Senitivity results from the regression of capital inflows and outflows on lags of GDP growth.

\begin{tabular}{|c|c|c|c|c|c|c|}
\hline Dependent variable: & $C I_{i W t}$ & $C I_{i W t}$ & $C O_{i W t}$ & $C O_{i W t}$ & $C N_{i W t}$ & $C N_{i W t}$ \\
\hline$\Delta y_{i t}$ & $\begin{array}{r}5.882^{* * *} \\
(0.894)\end{array}$ & $\begin{array}{r}3.366^{* * *} \\
(0.815)\end{array}$ & $\begin{array}{r}0.576 \\
(0.714)\end{array}$ & $\begin{array}{r}-0.557 \\
(0.676)\end{array}$ & $\begin{array}{r}5.306^{* * *} \\
(0.823)\end{array}$ & $\begin{array}{r}3.922^{* * *} \\
(0.630)\end{array}$ \\
\hline$\Delta y_{i t} \times$ Crisis $_{i t}$ & & $\begin{array}{r}0.893 \\
(1.200)\end{array}$ & & $\begin{array}{r}1.975^{* *} \\
(0.996)\end{array}$ & & $\begin{array}{r}-1.083 \\
(0.928)\end{array}$ \\
\hline Period FE & Yes & Yes & Yes & Yes & Yes & Yes \\
\hline Cross-section FE & Yes & Yes & Yes & Yes & Yes & Yes \\
\hline $\bar{R}^{2}$ & 0.110 & 0.149 & 0.082 & 0.112 & 0.084 & 0.108 \\
\hline Obs. & 1855 & 1675 & 1855 & 1675 & 1855 & 1675 \\
\hline Dependent variable: & $C I_{i j t}$ & $C I_{i j t}$ & $C O_{i j t}$ & $C O_{i j t}$ & $C N_{i j t}$ & $C N_{i j t}$ \\
\hline$\Delta y_{i t}$ & $0.037^{* * *}$ & -0.002 & $0.027^{* * *}$ & -0.013 & 0.010 & 0.011 \\
\hline$\Delta u$ & $\begin{array}{r}(0.010) \\
0000\end{array}$ & $\begin{aligned}(0.013) \\
-0.019^{* *}\end{aligned}$ & $0.033^{* * *}$ & $\begin{array}{l}(0.012) \\
0.019^{* *}\end{array}$ & $\begin{array}{r}(0.011) \\
-0.034^{* * *}\end{array}$ & $\begin{array}{r}(0.013) \\
-0.039 * * *\end{array}$ \\
\hline${ } g_{j t}$ & $(0.006)$ & $(0.008)$ & $(0.006)$ & $(0.008)$ & $(0.007)$ & $(0.008)$ \\
\hline$\Delta y_{i t} \times C r i s i s_{i t}$ & & $\begin{array}{r}0.104^{* * *} \\
(0.021)\end{array}$ & & $\begin{array}{r}0.029 \\
(0.021)\end{array}$ & & $\begin{array}{r}0.076^{* * * *} \\
(0.022)\end{array}$ \\
\hline$\Delta y_{j t} \times C r i s i s_{j t}$ & & $\begin{array}{r}0.039 * * * \\
(0.012)\end{array}$ & & $\begin{array}{r}0.013 \\
(0.011)\end{array}$ & & $\begin{array}{r}0.025^{* *} \\
(0.012)\end{array}$ \\
\hline Period FE & Yes & Yes & Yes & Yes & Yes & Yes \\
\hline Cross-section FE & Yes & Yes & Yes & Yes & Yes & Yes \\
\hline $\bar{R}^{2}$ & 0.031 & 0.032 & 0.028 & 0.031 & 0.035 & 0.036 \\
\hline Obs. & 23228 & 19277 & 23158 & 19266 & 22781 & 18986 \\
\hline
\end{tabular}

